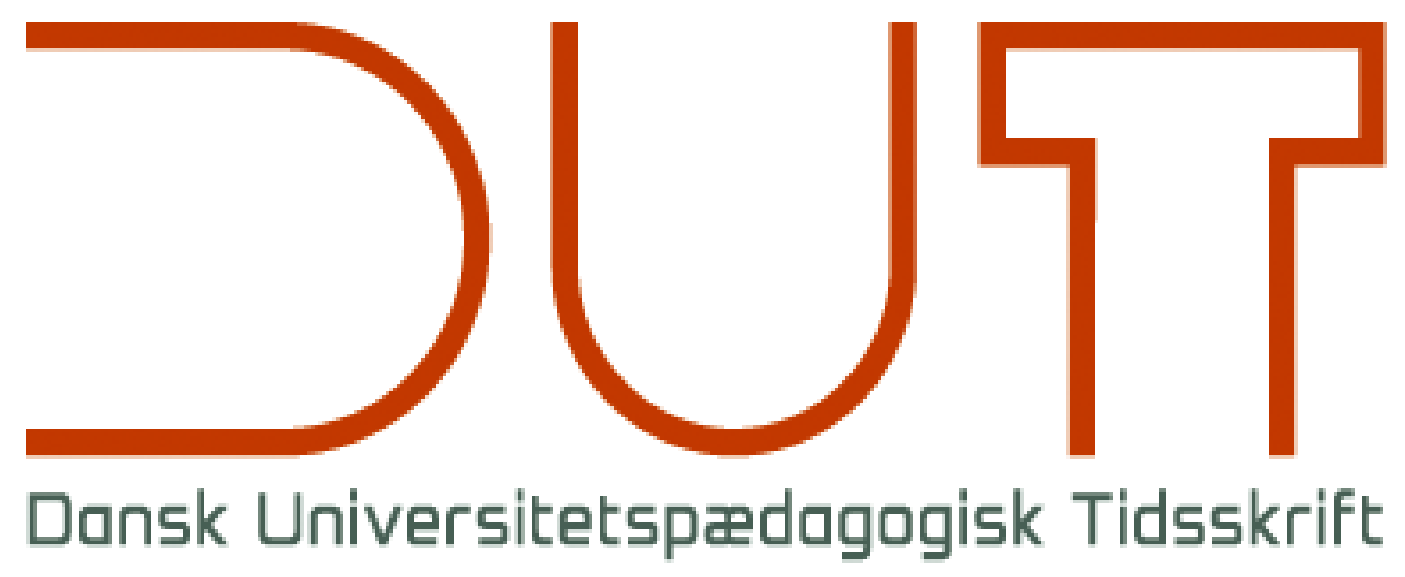

Tema

Fra data til beslutninger

Årgang 14 nr. 26 / 2019

Titel

1968: Studenteroprør og undervisningsrevolution. En fortælling om opgøret med traditionel universitetsundervisning

Forfattere

Sidetal

Udgivet af

URL

Birger Steen Nielsen

$139-142$

Dansk Universitetspædagogisk Netværk, DUN

> http://dun-net.dk/

Betingelser for brug af denne artikel

(C) Copyright
Denne artikel er omfattet af ophavsretsloven, og der må citeres fra den. Følgende betingelser skal dog være opfyldt:

- Citatet skal være i overensstemmelse med "god skik"

- Der må kun citeres „i det omfang, som betinges af formålet“

- Ophavsmanden til teksten skal krediteres, og kilden skal angives ift. ovenstående bibliografiske oplysninger.

DUT og artiklens forfatter 


\title{
1968: Studenteroprør og undervisningsrevolution. En fortælling om opgøret med traditionel universitets- undervisning
}

\author{
Skrevet af Finn Hansson \\ Udgivet 2018 på Roskilde Universitetsforlag, 117 sider, ISBN: 978-87-7867-512-5 \\ Anmeldt af Birger Steen Nielsen ${ }^{a, 1}$ \\ anstitut for Mennesker og Teknologi, Roskilde Universitet
}

Finn Hanssons bidrag til historieskrivningen om 68-oprøret (68) og dets virkninger skiller sig ud fra de ikke så få andre udgivelser i anledning af 50-året for 68. Den er som en række andre bidrag nok skrevet indefra - Finn Hansson var selv en central deltager i oprøret og har en lang universitetskarriere bag sig, der førte ham fra Sociologisk Institut på Københavns Universitet (KU) til Copenhagen Business School (CBS), hvor han bl.a. arbejdede som forskningsbibliotekar - og den trækker også på hans egne erindringer, men den kombinerer dette med et stædigt gravearbejde i bedste sociologisk tradition: Han har været vidt omkring og dybt nede i tilgængeligt kildemateriale, og det har gjort det muligt for ham at fortælle en anden historie om 68 end den gængse.

Det er historien om, hvordan opgøret med de stivnede og perspektivløse undervisningsformer og de måder at studere på, der prægede universitetet dengang, ikke bare var en vigtig side af oprøret, men også må ses som et omdrejningspunkt for det - en drivkraft - der dengang havde afgørende betydning for oprørets indre organisering og sammenhængskraft. En udvikling som derudover blev grundlaget for en pædagogisk og studiemæssig model, der har rakt langt ud over det kortvarige oprør i sig selv - med Hanssons indledende ord:

Alle steder i det danske uddannelsessystem arbejder man i dag med gruppearbejde og projekter. Denne paedagogiske model har eksisteret i mange år og har [...] vist sig at vorre ganske sejlivet. Men hvordan opstod den egentlig? Hvor kom den fra? Og hvordan blev den så udbredt? (s. 9)

\section{Gruppe- og projektarbejde: Hvor kom det fra?}

At 68 gav anledning til, at undervisningsformerne - mere eller mindre og med forskellig rækkevidde på de forskellige fag - blev grundlæggende fornyet, er ikke en ny iagttagelse. Men i Hanssons rekonstruktion af, hvordan det fandt sted, vil jeg fremhæve to dimensioner, der i særlig grad falder i øjnene. Den første dimension angår det andet af hans tre spørgsmål: Hvor kom denne pædagogik fra?

Bogens rekonstruktion er her rigt facetteret. Jeg hæfter mig ved, at det lykkes Hansson at vise, hvordan de pædagogiske forsøg på nyorientering kun kan forstås, hvis man ser, hvordan studenteroprøret var en del af både det langt mere omfattende ungdomsoprør med dets eksperimenteren med nye måder at mødes og leve sammen på - kollektive modkulturer

\footnotetext{
${ }^{1}$ Kontakt: bsn@ruc.dk
} 
- samtidig med, at der var stærke reformpædagogiske traditioner at trække på - traditioner, der på deres side var inspirationskilder for ungdomsoprøret og blev aktiveret og nyfortolket gennem det. Der henvises til denne sidste side, men det er først og fremmeste den første, Hansson forbilledligt beskæftiger sig med. Herigennem bidrager hans fortælling - ud over dens hovedærinde - også til at tegne et langt mere nuanceret billede af "det politiske 68" end det, der fortrinsvis verserer. Ikke bare i betydningen, at "det politiske 68" var mere end politik, men mere grundlæggende i den forstand, at "det politiske" var uløseligt forbundet med forsøget på at skabe nye måder at leve på. I det perspektiv er det et scoop, at hans hoved-"case" er dét Sociologiske Institut, der vel nok står som eksemplet på den radikale, marxistisk orienterede studenterbevægelse.

"Det alternative", orienteringen mod nye livsformer og "det politiske" - stærkest markeret i protesterne mod Vietnamkrigen og den teoretiske orientering mod en ny, kritisk marxisme løb sammen i det, der var bevægelsens centrale kendetegn: det antiautoritære, positivt formuleret: ønsket om autonomi. Man ønskede frie, selvbestemte undervisnings- og studieformer, fordi de gamle ikke var til at ånde i, men også for at kunne gøre studierne "samfundsrelevante": kritiske. Denne bestræbelse udløste uanede energier og opfindsomhed. Der blev arbejdet hårdt, både med omformningen af undervisnings- og studieformerne og med de kritiske faglige studier og undersøgelser.

\section{Hvordan kunne den nye pædagogik slå igennem?}

Den anden dimension, jeg vil fremhæve, besvarer Hanssons tredje - ovenstående - spørgsmål. Der blev lagt masser af arbejde i selvorganiseringen af studium og undervisning, men samtidig også med udformningen af nye studieordninger. Det var år med en intensiv mødeaktivitet, stormøder, gruppemøder, men også studienævns- og institutmøder. Det giver bogen et levende billede af - et billede, der samtidig viser, hvordan det forstokkede og autoritære institutmiljø, der generelt kendetegnede universitetet, men i scerlig grad Sociologisk Institut, også udgjorde en selvstændig drivkraft til oprøret - en drivkraft, der havde form af oprør, modstand og nok også med elementer af militant uforsonlighed, som ikke uden videre harmonerede med frihedsbestræbelsen. At karakteristikken af datidens Sociologisk Institut som autoritært og forstokket ikke blot er et partsindlæg, viser bogen - gennem sit kildemateriale, herunder Rektor Mogens Fogs udtalelser og indgreb - overbevisende.

Uden studenternes ihærdighed og vedholdende engagement kunne den nye pædagogik ikke have slået igennem. Det er imidlertid bogens store fortjeneste - som historieskrivning og fortolkningsramme til at forstå denne vidtgående samfundsmcessige reformproces - at den viser, hvordan studenternes bestræbelser "nedefra", uden at de vidste af det, imødekom delvist strandede - bestræbelser fra centraladministrationen, der ønskede et opgør med universiteternes ældgamle autonomi, som blev anset for blokerende for moderniseringen af det danske samfund, hvor netop uddannelsessektoren blev betragtet som et væsentligt moment i opbygningen af vækst- og velfærdssamfundet. 68-oprøret blev grebet som en anledning til at få gang i denne reformproces. Det er en spændende og tankevækkende historie, som jeg kun kan anbefale, man selv læser efter i bogen.

Resultatet blev jo ikke bare en uskadeliggørelse af oprørets bestræbelser, men en vidtgående institutionalisering af dem i former, der ganske vist var modsigelsesfulde, men altså også indebar en virkelig fornyelse og åbning af universitetet, som af de studerende (os) dengang nok blev betragtet som mangelfulde, men også som en sejr. Universiteternes nærmest feudale autonomi - professorvældet - var en stopklods for en fri og kritisk videnskab, og uden 
kompromiset med "statsmagten" var en reformering ikke lykkedes. Men set i et aktuelt perspektiv var åbningen for den statslige intervention i universiteternes styre jo også et tveægget sværd. I dag står etableringen af en stærkere autonomi på universiteterne igen på dagsordenen, men i en helt anden politisk-økonomisk konstellation, hvor en kulturkonservativ tilbagevenden til det traditionelle autonome universitet, selv hvis den kunne lade sig gøre, ville være perspektivløs.

I studenternes perspektiv beskriver Hansson arbejdet med at udforme og bidrage til indførelsen af den nye pædagogik som en omfattende læreproces, bestemt af lige dele opfindsomhed og "administrativt håndværk". Især fremhæver han, hvordan det var nødvendigt, at man lærte sig at bruge et administrativt sprog, der kunne ligge langt fra de aktivistiske former for retorik, der jo også prægede oprøret. Det ligner det, som Knud Illeris senere kaldte en "dobbelt-kvalificering", og betydningen heraf vurderes i bogen højt og beskrives bl.a. i forhold til indførelsen af gruppe- og projektarbejde ved de nyoprettede universitetscentre. Det peger frem mod den indflydelse, som studenterrådene og DSF i mange årtier har kultiveret og udøvet. Men måske gås der lidt for hurtigt uden om tvetydighederne i denne form for dobbeltkvalificering?

\section{Oprørets universitetspædagogiske frugter - $\mathrm{i}$ dag}

Bogens afsæt er, som forordet beskriver, at "alle steder i det danske uddannelsessystem arbejder man i dag med gruppearbejde og projekter". 68 lever videre. Men hvis man skulle ønske sig mere, end det bogen giver, kunne det være en mere indgående diskussion af denne vurdering. I hvert fald inviterer den til det. Hansson åbner selv denne diskussion, men udfolder den ikke. Hans ærinde har også væsentligt været et stykke korrigerende, sociologisk historieskrivning. En nærmere beskæftigelse med selve gruppe- og projektpcedagogikken med sammenhængen mellem læringsformer og kritisk erkendelse er der ikke. Det kunne måske have givet anledning til udfoldelse af diskussionen om denne pædagogiks status i dag.

For der er gode grunde til at spørge, hvor meget der egentlig er tilbage af det kritiske og skabende projekt- og gruppearbejde fra 68. Måske ikke så meget. Hansson nævner selv, at universitetsdemokratiet er blevet afskaffet, men det rækker jo langt ind i undervisnings- og studieformer. Rekonstruktionen af den nye pædagogiks opkomst viser bl.a. også, at dens centrum og indre drivkraft var knyttet til studenternes stræben efter autonomi og ønsket om, at deres studier skulle have kritisk samfundsrelevans. Demokratisering af universiteterne var uadskilleligt forbundet hermed. I dag er det institutionelle perspektiv snarere "samfundsrelevans uden kritik". Og hvor "selvvalgt" er tilgangen i "gruppearbejde og projekter" i dag i "det danske uddannelsessystem"? Dette kan man selvfølgelig - på universiteterne, i hvert fald søge at træde op imod. Og det sker jo også. Men her virker den stærke beskæring af studietid, kravet om hurtigere gennemførelse og ønsket om kortere studier kontraproduktivt.

Studerende og lærere kan stadig i et vist omfang finde omveje, tage sig tid og gå imod hovedtendensen. Og som bogens historie viser, er modstand ikke den ringeste drivkraft. Man skal heller ikke glemme, at projekt- og gruppearbejde stadig i sig selv har en iboende tendens mod at åbne for autonomi i læreprocesserne. Det er en pædagogik, der ikke fuldstændig kan teknokratiseres, men som også kan opfordre til "usædvanlige læreprocesser", som det engang hed. Også i dag findes der hos studenter og unge mennesker i det hele taget - på ny og måske i voksende omfang - stærke ønsker om et rigtigt og meningsfuldt liv og om en uddannelse, hvor man kan beskæftige sig med noget vigtigt; noget der betyder noget. Og sådanne øn- 
sker kan netop 68-pædagogikken komme i møde. Det kan Finn Hanssons storartede bog også minde os om. 